\title{
Plasma iron values in National Blood Transfusion Service donors
}

\author{
E. A. FRENCH AND PUSHPA K. SITLANI \\ From the Haematology Department, St. George's Hospital, London, and South London \\ Blood Transfusion Centre, Sutton, Surrey
}

SYNOPSIS Haemoglobin, haematocrit, and plasma iron values were estimated on blood sampleș collected from 100 male and 113 female National Blood Transfusion Service blood donors, andos from 83 male and 66 female age-matched control subjects. No significant differences in any of theseog values were found to exist between the donors and controls, and it is considered that the serum oro plasma iron level is unsuitable for use as a screening test of early iron deficiency in donors.

It is a matter of concern to a transfusion service that its donors should experience no ill effects, and especially so where recruitment of donors is on a voluntary basis. On the other hand, increasing demands both for blood and blood products dictate that the available supply of donors be used to the best possible advantage, and that individual donors be bled at the shortest intervals that will allow full replenishment of the losses incurred.

The most probable effect of repeated blood donations is iron deficiency, accentuated by the low iron content of many diets and the relatively inefficient absorptive mechanisms concerned. Such a deficiency may coexist with a normal level of circulating haemoglobin (Stafford and Kemp, 1954; Fielding, O'Shaughnessy, and Brunström, 1965) and therefore the routine haemoglobin screening test applied to donors does not exclude all those who may be failing to make good their iron losses.

Donors in the National Blood Transfusion Service (NBTS) are called up at intervals of not less than six months and give $430 \mathrm{ml}$ of blood, including samples. In the region covered by the South London Blood Transfusion Centre, donors are bled if their haemoglobin level exceeds $12.4 \mathrm{~g} / 100 \mathrm{ml}(85 \%)$ by a copper sulphate specific gravity method; it is not the practice to give them supplementary iron.

Laurell (1947) was able to demonstrate low serum iron values in donors, but his subjects had given some $2,500 \mathrm{ml}$ over the previous 12 months. Remy, Goldeck, and Krüger (1952) also demonstrated a tendency towards low values in donors giving 1,200 to $1,500 \mathrm{ml}$ in a year, but Hagberg, Wallenius, and Wranne (1958) found no change in serum iron and Received for publication 13 March 1969. total iron-binding capacity (TIBC) in donors whot had been bled on up to four occasions in the previous? 12 months. Kaldor (1953) found both three-monthly $\overrightarrow{c o}$ donors and controls to have similar mean serum? iron values, although in his female groups differences of doubtful significance were recorded.

Iron absorption tests have been used in similar studies: Heistø and Foss (1958) found that the risen in serum iron following an oral dose increased in subjects who had given blood, as compared with normal controls, that this increase became more? marked after further blood donations, and that it could be reversed by iron replacement therapy Berde, Holländer, Undritz, and Zehnder (1955) reported that a similar test gave normal resulto provided that donations did not exceed $1,000 \mathrm{mb}$ per 12 months. However, iron absorption tests are not feasible for the screening of blood donors sinces they involve fasting overnight and the collection of samples for several hours after the oral dose of iron?

The present investigation records plasma iron values, haemoglobin and haematocrit levels, in series of NBTS donors and in control subjects, with the object of seeing whether regular blood donation produces any significant change. Comparison of serum or plasma iron levels can only usefully beస్ట made between mean values for different groups, since individual values are subject to quite wide variations dependent upon a number of factor (Zilva and Patston, 1966).

\section{MATERIALS AND METHODS}

The subjects were all donors attending NBTS session who had donated three or more times, the last previous 
donation being within 12 months. Age-matched controls were either potential donors attending for the first time, or healthy workers attending the Medical Department, British Railways Southern Region, London Bridge. Controls in the latter group were questioned and selected in the same way as are prospective blood donors. Donors and controls were excluded from this study if they had received any recent iron therapy. The age range of both groups was 18 to 65 .

SAMPLING Blood was taken into lithium heparin for plasma iron estimation (equivalent to the serum level by the method used), and into EDTA for haemoglobin and haematocrit determination. From donors, the samples were taken via the collecting set at the end of the donation, while with controls who were not donors, simple venepuncture with minimal venous stasis was used. From a small series of donors bled at St. George's Hospital blood was taken by both methods and the relevant values compared in the pre- and post-donation samples.

METHODS Haemoglobin levels were measured by a routine cyanmethaemoglobin method using an EEL Spectra colorimeter and haematocrits were determined by a microcentrifugation method. Plasma iron estimations were carried out on the AutoAnalyzer using the method of Young and Hicks (1965).

\section{RESULTS}

1 COMPARISON OF PRE- AND POST-DONATION VALUES The 'pre-donation' sampling is equivalent to the method used in 53 of the male controls, that is, those not bled at NBTS donor sessions. All other figures were obtained from post-donation samples, the blood being taken after a period of about five minutes with a cuff inflated to 40 to $60 \mathrm{~mm} \mathrm{Hg}$ on the arm used. All values were higher in the predonation samples, the mean differences being: haemoglobin concentration $0.5 \mathrm{~g} / 100 \mathrm{ml}$; haematocrit $1.8 \%$; plasma iron $6.8 \mu \mathrm{g} / 100 \mathrm{ml}$. Individual shifts of plasma iron ranged from 2 to $10 \mu \mathrm{g} / 100 \mathrm{ml}$ in the 10 donors studied in this way.

2 PlASMA IRON VAlUES IN DONORS AND CONTROLS These are set out for males and females respectively in Tables I and II. In the total values for the groups, neither sex shows any significant difference in mean plasma iron between donors and controls. No correction has been made in the tables for the 52 male controls bled by simple venepuncture; if the effect shown in (1) above applies to the larger group then the mean plasma iron value for male controls should be lowered by about $4 \cdot 3 \mu \mathrm{g} / 100 \mathrm{ml}$ to make it more strictly comparable with that of male donors. In each donor group, about half had donated three to eight times previously, and a further quarter up to 14 times, the remainder ranging up to 64 donations. There was no apparent relationship between these figures and plasma iron levels.

3 HAEMOGLOBIN AND haEMATOCRIT VALUeS Here again, no significant differences were found between donors and controls of either sex. Mean haemo-

TABLE I

RESULTS IN MALES

\begin{tabular}{|c|c|c|c|c|c|c|}
\hline \multirow[b]{2}{*}{$\begin{array}{l}\text { Age Range } \\
\text { (yr) }\end{array}$} & \multicolumn{3}{|l|}{ Male Donors } & \multicolumn{3}{|l|}{ Male Controls } \\
\hline & No. in Group & $\begin{array}{l}\text { Mean Plasma Iron } \\
(\mu \mathrm{g} / 100 \mathrm{ml})\end{array}$ & $S D$ & No. in Group & $\begin{array}{l}\text { Mean Plasma Iron } \\
(\mu \mathrm{g} / 100 \mathrm{ml})\end{array}$ & $S D$ \\
\hline $\begin{array}{l}18-29 \\
30-39 \\
40-49 \\
50-59 \\
60-65\end{array}$ & $\begin{array}{r}19 \\
26 \\
30 \\
22 \\
3\end{array}$ & $\begin{array}{r}120 \cdot 3 \\
103 \cdot 9 \\
103 \cdot 2 \\
87 \cdot 6 \\
124 \cdot 7\end{array}$ & $\begin{array}{l}34 \cdot 4 \\
34 \cdot 4 \\
42 \cdot 9 \\
29 \cdot 7 \\
32 \cdot 4\end{array}$ & $\begin{array}{l}20 \\
12 \\
20 \\
19 \\
12\end{array}$ & $\begin{array}{r}106 \cdot 6 \\
107 \cdot 2 \\
87 \cdot 4 \\
103 \cdot 6 \\
110 \cdot 8\end{array}$ & $\begin{array}{l}31 \cdot 0 \\
22 \cdot 5 \\
30 \cdot 6 \\
24 \cdot 1 \\
35 \cdot 6\end{array}$ \\
\hline Total & 100 & 103.9 & $39 \cdot 46$ & 83 & $102 \cdot 0$ & $30 \cdot 1$ \\
\hline
\end{tabular}

TABLE II

RESULTS IN FEMALES

\begin{tabular}{|c|c|c|c|c|c|c|}
\hline \multirow[b]{2}{*}{$\begin{array}{l}\text { Age Range } \\
(y r)\end{array}$} & \multicolumn{3}{|c|}{ Female Donors } & \multicolumn{3}{|c|}{ Female Controls } \\
\hline & No. in Group & $\begin{array}{l}\text { Mean Plasma Iron } \\
(\mu \mathrm{g} / 100 \mathrm{ml})\end{array}$ & $S D$ & No. in Group & $\begin{array}{l}\text { Mean Plasma Iron } \\
(\mu \mathrm{g} / 100 \mathrm{ml})\end{array}$ & $S D$ \\
\hline $\begin{array}{l}18-29 \\
30-39 \\
40-49 \\
50-59 \\
60-65\end{array}$ & $\begin{array}{r}25 \\
27 \\
25 \\
28 \\
8\end{array}$ & $\begin{array}{l}91.9 \\
92 \cdot 3 \\
71 \cdot 4 \\
92 \cdot 6 \\
92.5\end{array}$ & $\begin{array}{l}38 \cdot 5 \\
33 \cdot 2 \\
25 \cdot 5 \\
33 \cdot 0 \\
14 \cdot 8\end{array}$ & $\begin{array}{r}40 \\
14 \\
6 \\
6 \\
\text { nil }\end{array}$ & $\begin{array}{l}94.7 \\
81 \cdot 2 \\
83.7 \\
95 \cdot 7 \\
-\end{array}$ & $\begin{array}{l}44 \cdot 4 \\
39 \cdot 1 \\
14 \cdot 3 \\
30 \cdot 3 \\
-\end{array}$ \\
\hline Total & 113 & $87 \cdot 7$ & $33 \cdot 1$ & 66 & $91 \cdot 0$ & $40 \cdot 7$ \\
\hline
\end{tabular}


globin values for donors and controls were $\mathbf{1 4 . 8}$ $\mathrm{g} / 100 \mathrm{ml}$ and $15.2 \mathrm{~g} / 100 \mathrm{ml}$ (males), and $13 \cdot 1$ $\mathrm{g} / 100 \mathrm{ml}$ and $13.2 \mathrm{~g} / 100 \mathrm{ml}$ (females). The corresponding haematocrit values were $44 \%, 45 \%, 39 \%$, and $40 \%$ respectively.

A number of low haemoglobin values were found in all groups and some of these, in donors and donor controls, were too far below the $12.4 \mathrm{~g} / 100 \mathrm{ml}$ NBTS rejection level for the difference to be due to the sampling effect noted above. Of 11 donors with haemoglobin values below $11.9 \mathrm{~g} / 100 \mathrm{ml}$, the mean plasma iron level was $62 \mu \mathrm{g} / 100 \mathrm{ml}$ (range < 10-104).

\section{DISCUSSION}

Previous work, cited above, has shown evidence of some degree of storage iron depletion following repeated blood losses of the magnitude experienced by blood donors. Laurell (1947) found lowered serum iron levels in his donors, who were, however, being bled more frequently than is usually the case now. Other workers have reported changes in the iron absorption test following donations, and however these be interpreted, the finding that the test reverted to normal following iron treatment suggests that some degree of depletion had occurred (Remy et al, 1952; Berde et al, 1955; Heistø and Foss, 1958). More recently, the chelation of body iron by an administered dose of desferrioxamine has been used as a measure of body iron stores; in a series of 45 women with normal haemoglobin levels 15 $(33 \%)$ showed evidence of iron depletion (Fielding et al, 1965), while of 24 male blood donors who were incurring a mean annual loss of $900 \mathrm{ml}$, $10(41 \%)$ showed similarly abnormal results (Fielding, Karabus, and Brunström, 1968). The similar figures in these two groups possibly reflect a comparable rate of blood loss, $900 \mathrm{ml}$ annually, being roughly equivalent to a loss per menstrual cycle of $70 \mathrm{ml}$.

In the present study, plasma iron levels in male and female donors did not deviate from the normal controls; nor was there any difference when the females in the premenopausal age groups were judged separately. As a screening test for individual donors, the serum iron level has already been invalidated because of wide fluctuations related to the time of day, the menstrual phase, and the presence of minor infections, in addition to day-today fluctuations which also occur (Zilva ando Patston, 1966). The work of Fielding and his을 colleagues suggests that occult iron deficiency occurs $\frac{\bar{c}}{\bar{T}}$ both in healthy menstruating females and in male $\stackrel{\mathbb{\Omega}}{\Omega}$ blood donors. The failure in the present study too demonstrate any fall in mean plasma iron amongst ${ }^{\infty}$ menstruating females who are also blood donors? suggests that the serum/plasma iron level is an $\vec{\omega}$ insufficiently sensitive index of iron depletion to be $\stackrel{\omega}{\circ}$ of value even for group studies. The only group in whom a lowered plasma iron level could be showniv was that of 11 subjects, both donors and controls, $\stackrel{N}{\circ}$ in whom there was evidence of early anaemia.

Anyone donating blood at intervals of three ${ }^{\infty}$ months should receive supplementary oral iron; of $\frac{}{5}$ those being bled six-monthly about a third of themales and presumably a higher proportion of the $Z$ females would also benefit by being given iron. At

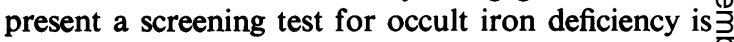
lacking, at least one sufficiently cheap and simpleథ to be applicable on a large scale to NBTS blood $\overrightarrow{\mathscr{\theta}}$ donors.

Our thanks are due to Mrs P. J. Maitland who carried out the plasma iron determinations, and to Professor J. L. Stafford for much helpful criticism and encouragement. $\bar{\partial}$ We wish also to thank Dr R. A. Zeitlin for permission to carry out this study on donors to the South London Blood $\stackrel{\mathbb{Q}}{\square}$ Transfusion Centre; also Dr T. P. Howkins and Dr A. H. Jones for making available the facilities of the British윽 Railways Southern Region Medical Department to obtain control samples.

\section{REFERENCES}

Berde, B., Holländer, L., Undritz, E., and Zehnder, K. (1955). Schweiz. med. Wschr., 85, 936.

Fielding, J., Karabus, C., and Brunström, G. M. (1968). J. clin. Path., $21,402$.

-, O'Shaughnessy, M. C., and Brunström, G. M. (1965). Lancet, $2,9$.

Hagberg, B., Wallenius, G., and Wranne, L. (1958). Scand. J. clin. Lab. Invest., 10, 63.

Heistø, H., and Foss, O. P. (1958). Ibid., 10, 102.

Kaldor, I. (1953). Aust. J. exp. Biol., 31, 49.

Laurell, C.-B. (1947). Acta physiol. scand., 14, suppl. 46.

Remy, D., Goldeck, H., and Krüger, E. (1952). Dsch. med. Wschr. $77,1253$.

Stafford, J. L., and Kemp, N. H. (1964). Sangre, 9, 410.

Young, D. S., and Hicks, J. M. (1965). J. clin. Path., 18, 98.

Zilva, J. F., and Patston, V. J. (1966). Lancet, 1, 459.

(1)

